\title{
Development of Materials in Materials Module With Appropriate Resolution Application
}

\author{
Ririn Dwi Agustin, Firda Alfiana Patricia \\ Mathematics Education \\ IKIP Budi Utomo Malang \\ Indonesia
}

\begin{abstract}
The purpose of this research is (1) development of matrix module with problem solving approach for vocational students of class X. (2) To know and describe the quality of matrix module with problem solving approach in XK SMK students viewed from the aspect of validity, effectiveness, and practicality. This research is a development research using 4-D development model. In this development model is adopted until the third stage of $D$, namely the development stage due to time constraints and tailored to the needs and development of the module. This research produces matrix module with problem solving approach for students of class X SMK. The result of the research shows that: (1) based on the evaluation of the quality of the module by the validator, the module is valid with $79 \%$ percentage and the category is good, (2) based on the pilot test developed module is effective with $80 \%$ test error, 3 ) based on student response questionnaire developed module expressed practical with $84 \%$ percentage and very good category.
\end{abstract}

Keyword-Matrix; Problem Solving; Development

4-D

\section{INTRODUCTION}

In learning mathematics, ideally students are accustomed to gain understanding through experience and knowledge developed by students in accordance with the development of thinking. Because students have different potential in the functioning of their thinking ability. This is in line with the learning objectives formulated by the National Council of Teachers of Mathematics [1] that students must learn mathematics through understanding and actively building new knowledge from previously possessed experiences and knowledge.

According to [2] The ability of students in solving problems is closely related to intellectual development. Thus the difficulty level of the problems given to the students must be adjusted to the development of students. The theme of the given problems should be taken from the daily (contextual) events that are closer to the student's life.

To achieve the purpose of learning mathematics, one. In order for students to master their own processes, systematic steps are required to guide students to solve problems.

On the one hand the availability of a quality textbook is still lacking. The authors of textbooks do not understand how the books are so easily understood by students. The rules of learning psychology and design theories of a textbook are not applied in the preparation of textbooks. Finally, students find it difficult to understand the book they read but it also looks boring. The module is a unit of instruction program organized in a certain form for learning purposes. According to the meaning of the original term the module is a complete measuring instrument, a unit that can function independently, separately, but also can function as a unity of all other units. In fact the module is a planned type of learning activity, designed to assist students individually in achieving their learning objectives.

Matrix is one of the materials taught to students of class X of SMK. In everyday life the matrix can be used to solve systems of linear equations, geometry transformations, computer programs, and others. But the matrix material is still often considered difficult and abstract. As well as in a book published by the Ministry of Education and Culture of the Republic of Indonesia used in SMK PGRI 3 Malang, matrix material is taught in class $\mathrm{X}$ and Class XII whereas matrix material is taught in class $\mathrm{X}$ only. This is the background of choosing matrix material in this research.

\section{RESEARCH METHODOLOGY}

The research design used in developing this module is a 4-D development model. According to [3] The device development model as suggested by Thiagarajan and Semmel is Model 4-D. This model consists of 4 development stages of Define, Design, Develop, and Disseminate. In this development model is adopted until the third stage of $\mathrm{D}$, the stage of development (development). (1) In the Define stage includes five basic steps, namely (a) Analysis of the front end, (b) Student analysis, (c) Task analysis, (d) Concept analysis, and (e) formulation learning objectives. (2) In the Design stage, theme selection, selection of initial design and format, reference selection, test preparation and layout design are made. (3) Development stage consists of: (a) Preparation of matrix module with problem solving approach in accordance with the results of the analysis planning. (b) Assessing the quality of the module (module validation) before the test is tested (c) Initial revision after the module quality assessment. (d) The revised module is tested for 
10 students to be asked to study and solve problems in the Matrix module.

Research instrument used: (1) Module validation sheet used to know the level of validity and module. This module validation sheet aims to obtain suggestions and inputs to the matrix module. The module validation sheet is used by the validator to assess the eligibility of the module from various aspects including material, language, and module appearance. (2) Questionnaire response is used to measure the practicality of the module. The student response questionnaire contains statements that represent students' responses after observing the module the researchers developed. (3) Trial conducted on 10 students. The results of this limited trial are used to revise the modules that have been made. If the results of this limited trial get a good response and students can complete the test question according to the standard specified then the module is said to be effective.

For a validity level basis

TABLE I. Invalid criteria and module revisions

\begin{tabular}{cc}
$\begin{array}{c}\text { Percentage } \\
(\%)\end{array}$ & Criteria \\
\hline$p>\mathbf{8 0}$ & Very Good (No Revision needed) \\
& Good (No Revision needed) \\
$\mathbf{6 0}<\boldsymbol{\mathbf { 4 }}<\boldsymbol{p} \leq \mathbf{8 0}$ & Good Enough (Revised) \\
$\mathbf{2 0}<\boldsymbol{p} \leq \mathbf{4 0}$ & Not good (Revised) \\
$p \leq \mathbf{2 0}$ & Poor (Revised) \\
\hline & {$[4]$}
\end{tabular}

Data derived from the trial will be analyzed quantitatively to find out the average grade and learning mastery. Here are the scoring guidelines and test assessments.

- Each test item has a different weight score according to the level of difficulty of each question.

- From the number of scores obtained then calculated the value of students with the formula

student score $(\mathrm{x})=$ total score

- Completeness of individual learning (minimum mastery criteria) is 75

- Completed tests are calculated by:

TABLE II : Complete Testing Criterion

[4]

\begin{tabular}{cc}
\hline Precentage (\%) & $\begin{array}{c}\text { Criteria Results } \\
\text { Student Response } \\
\text { Questionnaire }\end{array}$ \\
\hline$p>\mathbf{8 0}$ & Very Good \\
$\mathbf{6 0}<p \leq \mathbf{8 0}$ & Good \\
$\mathbf{4 0}<p \leq \mathbf{6 0}$ & Good Enough \\
$\mathbf{2 0}<p \leq \mathbf{4 0}$ & Not Good \\
$p \leq \mathbf{2 0}$ & Poor \\
\hline
\end{tabular}

[4]

\section{RESULT AND DISCUSSION}

In the Define stage in determining and setting learning requirements begins with an analysis of the objectives of the material constraints developed by the device. This stage includes 5 main steps, namely: (1) Analysis of the front end, done by analyzing the core competencies and basic competencies as well as indicators of achievement of competence with reference to Curriculum 2013. (2) Student analysis is done by looking at student value X TKJ A semester one on matrix material. From the data shows that the student's score has not been maximal yet. One of the causes is the book supporting the learning is still small and incomplete, for material matrix students do not get the supporting book that suits the needs of students. This is because the matrix material in Vocational High School (SMK) is taught in class X only, while the book used in teaching and learning process of matrix matter is divided into 2 in class $\mathrm{X}$ with matrix understanding material, matrix type, transpose matrix, equality of two matrices , counting operations on the matrix, inverse and determinant of the order matrix. And in class XII is given the material of minor matrix, cofactor, inverse and determinant of order matrix. (3) Task analysis is done to detail the content of teaching materials in the form of outline. Based on the results of interviews with teachers mathematics SMK PGRI 3 Malang about matrix material known that the material taught up to the inverse matrix .

So the matrix material contained in the module is presented in 4 learning activities. Learning activity 1 contains material understanding of matrix, matrix types, transpose and similarity of two matrices. Learning activity 2 contains matrix addition material, matrix reduction, and matrix multiplication with scalar. Learning activity 3 contains matrix multiplication materials with matrix and matrix determinants. While learning activity 4 contains minor matrix, cofactor matrix and inverse matrix. (4) Analysis concepts at this stage of analysis - analysis conducted is the analysis of core competence and competence and analysis of teaching materials. (5) Formulation of Learning Objectives contains the results of task analysis and concept analysis.

In the Design stage consists of (1) the selection of the theme of this module is developed with a problem-solving approach so that the module is given problem-solving problems that make students can think critically because the way of solving it is not as usual. In the module is also given problems with common problems that often occur around the goal students can better understand the matrix material and do not consider it abstracts. (2) Selection of initial format and design. this module is arranged with A4 size of $21 \mathrm{~cm} \mathrm{x} 29.7 \mathrm{~cm}$. using Cambria Math font size 12. (3) Preparation of material concepts from various references. Researchers seek and collect relevant reference books as a reference in developing modules. The reference books are: Advanced Mathematics for Class XII SMA / MA Language Program, Mathematics Technology Group, Health, and Agriculture For Vocational High School Class X, Mathematics Module For SMK - X Curriculum KTSP, Application Matic Volume III and Mathematics Textbook SMK Group Business Management. In addition to reference books, 
researchers also collect pictures downloaded from the internet and some are personal collections of authors. (4) The test and module layout design is divided into 3 parts, namely the beginning, the contents, and the end: (a) The initial section consists of: Cover or cover module, identity page, introduction, table of contents, introduction, and map concept. (b) The content section consists of: Introduction page, description of the material, sample questions, exercise questions, formative tests, retraining exercises and summaries (c) The final section consists of: glossary and bibliography. (5) Module Making.

At development stage done (1) Preparation of matrix module with problem-solving approach in accordance with the analysis results planning

a) Assessing the quality of the module (module validation) before tested Module that has been developed then consulted to the supervisor to get suggestions for improvement. After some improvements have been made, the module is then validated. The module developed in this research was validated by two lecturers from the Mathematics Education Department of IKIP Budi Utomo Malang and one mathematics teacher of SMK PGRI 3 Malang

b) The revised module is tested for 10 students. (4) The final product produced is a matrix module with problem-solving approach for SMK

\section{CONCLUSION}

Development of matrix module with problem solving approach for X class high school students using 4D (Define, Design, Develop, and Desseminate). In this development was adopted until the third stage of D Develop (Development).

Based on the assessment of validator that has been described previously all the aspects of the assessment of the matrix module is valid that is $79 \%$. In addition, based on the results of trials of ten matrix modules declared effective with
$80 \%$ percentage. Pursuant to result of questionnaire of student response $84 \%$ expressed practical with percentage. Then module declared valid, effective and practical.(1) The matrix module for students of Vocational High School class X can be further developed by other researchers for other mathematical materials. (2) The matrix module for X-Grade Vocational High School students may be further developed for teaching materials at SMK. Matrix module is feasible in perfected both in terms of material, terms of appearance and facet of development. In order to be developed until the last stage of the stage disseminate. (3) Testing can be done periodically on each sub-chapter material contained in the module. And do the test with a larger scale again.

\section{REFERENCES}

[1] Nindy Citoresmi, Sugiatno, D.S, Pengembangan Modul Matematika Berbasis Masalah Untuk Meningkatkan Kemampuan Penyelesaian Masalah Dan Berpikir Kreatif Matematis Siswa, Program Studi Magister Pendidikan Matematika FKIP UNTAN, 2016.

[2] I. Rizkianto, Workshop Kemampuan Pemecahan Masalah Topik Aljabar Bagi Guru Smp Di Kabupaten Sleman Yogyakarta. Retrieved from Workshop Kemampuan Pemecahan Masalah Topik Aljabar Bagi Guru Smp Di Kabupaten Sleman Yogyakarta.

[3] Trianto, Mendesain Pembelajaran Kontekstual (Contextual Teaching And Learning, Cerdas Pustaka, 2008.

[4] E. P. Widyoko, Evaluasi Program Pembelajaran, Yogyakarta: Pustaka belajar, 2009. 